Article

\title{
Stepwise Synthesis, Hydrogen-Bonded Supramolecular Structure, and Magnetic Property of a Co-Mn Heterodinuclear Complex
}

\author{
Ryoji Mitsuhashi *, Takaaki Ueda and Masahiro Mikuriya ${ }^{(D)}$ \\ Department of Applied Chemistry for Environment, School of Science and Technology, \\ Kwansei Gakuin University, 2-1 Gakuen, Sanda 669-1337, Japan; taka27013215@gmail.com (T.U.); \\ junpei@kwansei.ac.jp (M.M.) \\ * Correspondence: mitsuhashi@kwansei.ac.jp; Tel.: +81-79-565-8366
}

Received: 31 December 2018; Accepted: 14 January 2019; Published: 20 January 2019

check for updates

\begin{abstract}
A cobalt(III)-manganese(II) heterometallic dinuclear complex, $\left[\mathrm{Mn}^{\mathrm{II}}\left\{\mathrm{Co}{ }^{\mathrm{III}}(\mu-\mathrm{Himn})_{3}\right\} \mathrm{Cl}_{2}\left(\mathrm{CH}_{3} \mathrm{OH}\right)\right]$, was prepared by a metalloligand approach. X-ray crystallographic analysis indicated that the metalloligand [Co $\left.\mathrm{Co}^{\mathrm{III}}(\mathrm{Himn})_{3}\right]$ underwent mer/fac geometrical isomerization upon coordination to a $\mathrm{Mn}$ ion. Owing to the non-coordinating $\mathrm{N}-\mathrm{H}$ bonds in the $\left[\mathrm{Co}^{\mathrm{III}}(\mathrm{Himn})_{3}\right]$ moiety, the heterodinuclear complex exhibited hydrogen bond interactions with the $\mathrm{Cl}^{-}$ligand of the neighboring complex to construct two-dimensional hydrogen-bond networks. The bond distances around the Mn center and the $\chi_{M} T$ value at $300 \mathrm{~K}$ indicate that the $\mathrm{Mn}$ center is in a divalent state. The temperature dependence of the $\chi_{M} T$ product and field dependence of the magnetization showed the isotropic nature of the $\mathrm{Mn}^{\mathrm{II}}$ center.
\end{abstract}

Keywords: cobalt(III)-manganese(II) heterometallic complex; Crystal structure; magnetism; hydrogen-bonded supramolecular structure

\section{Introduction}

Discrete cobalt and manganese complexes have been attracting much attention owing to their fascinating magnetic properties such as single-molecule magnet behavior [1-5]. Heteronuclear complexes are strong candidates for such a property because of the magnetic coupling between different paramagnetic metal ions [6]. On the other hand, the combination of paramagnetic and diamagnetic ions is also a nice approach to prepare a single-molecule magnet with a single magnetic center (single-ion magnet) [7-9]. One of the advantages of single-ion magnets is facile control of the coordination geometry and crystal field to achieve a large negative axial zero-field splitting, which results in a high spin-reversal barrier. Sørensen et al. reported an excellent approach in which a $C_{4}$ symmetric diamagnetic metalloligand was employed to prepare $D_{4 d}$ symmetric $\mathrm{Ln}^{\mathrm{III}}$ single-ion magnets [8,9]. In our previous study, we reported a tris-bidentate-chelate cobalt(III) complex as a tridentate metalloligand to obtain a $\mathrm{Co}^{\mathrm{III}}-\mathrm{Co}^{\mathrm{II}}-\mathrm{Co}^{\mathrm{III}}$ mixed-valent complex [4]. The $\mathrm{Co}^{\mathrm{II}}$ ion in this complex takes ideal $D_{3 d}$ symmetry owing to the rigid $C_{3}$ symmetric metalloligand and intermolecular hydrogen bonding interactions. This stepwise reaction strategy can be applied to other first-row $\mathrm{d}$-block metal ions to obtain heterometallic complexes. To extend our study to a heterometallic complex, we report the synthesis and crystal structure of a Co-Mn dinuclear complex using a tris-bidentate cobalt(III) complex as a metalloligand. 


\section{Results and Discussion}

\subsection{Synthesis and Characterization}

The tris-bidentate-chelate metalloligand, [Co $\left.{ }^{\mathrm{III}}(\mathrm{Himn})_{3}\right]$, was synthesized by the reaction of $\mathrm{CoCl}_{2} \cdot 6 \mathrm{H}_{2} \mathrm{O}$ and $\mathrm{Himn}^{-}$in a 1:3 ratio in methanol in air (Scheme 1). The methanol solution of the metalloligand was added to a methanolic solution of $\mathrm{MnCl}_{2} \cdot 6 \mathrm{H}_{2} \mathrm{O}$ under a $\mathrm{N}_{2}$ atmosphere to afford brown crystals of the Co-Mn heterometallic complex. The obtained crystalline product was stable in air.
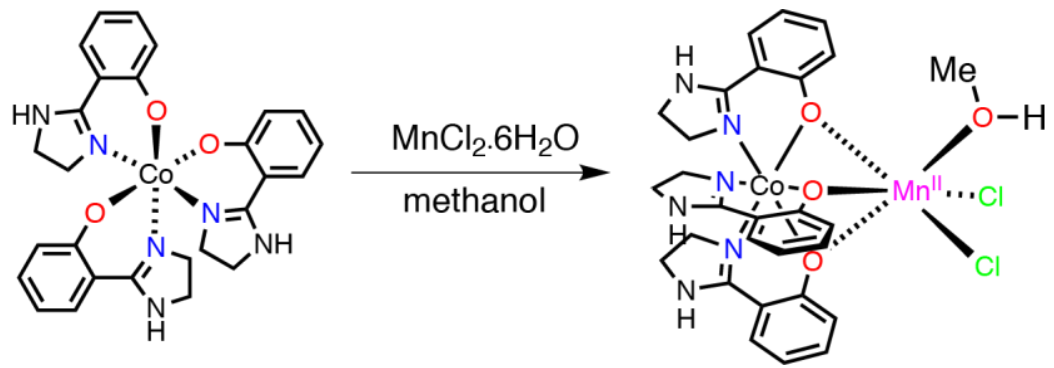

Scheme 1. Synthetic procedure of the Co-Mn heterodinuclear complex. The metalloligand $\left[\mathrm{Co}{ }^{\mathrm{III}}(\mathrm{Himn})_{3}\right]$ undergoes mer to fac isomerization upon coordination to a $\mathrm{Mn}^{\mathrm{II}}$ ion.

The heterometallic dinuclear complex, $\left[\mathrm{Mn}\left\{\mathrm{Co}(\mu-\mathrm{Himn})_{3}\right\} \mathrm{Cl}_{2}\left(\mathrm{CH}_{3} \mathrm{OH}\right)\right] \cdot 0.78 \mathrm{CH}_{3} \mathrm{OH} \cdot 1.26 \mathrm{H}_{2} \mathrm{O}$, was characterized by single-crystal $\mathrm{X}$-ray analysis. The molecular structure and crystallographic information are shown in Figure 1 and Table 1, respectively. In the crystal, the metalloligand, $\left[\mathrm{Co}(\mathrm{Himn})_{3}\right]$, coordinated to a $\mathrm{Mn}$ center via phenolate-O atoms as a tridenate ligand with the fac geometry. As the as-synthesized metalloligand takes the mer configuration in $100 \%$ yield, the metalloligand underwent mer/fac isomerization upon addition of $\mathrm{Mn}^{\mathrm{II}}$ ions [10]. This facile isomerization is presumably because of the partial formation of labile $\left[\mathrm{Co}^{\mathrm{II}}(\mathrm{Himn})_{3}\right]^{-}$owing to the $\left[\mathrm{Co}(\mathrm{Himn})_{3}\right]^{0 /-}$ redox equilibrium induced by $\mathrm{Mn}^{\mathrm{II}}$ ions [4]. Thus, we succeeded in designing a Co-Mn heterometallic complex by the metalloligand approach.

In the heterometallic complex, the Co center took $\mathrm{N}_{3} \mathrm{O}_{3}$ octahedral coordination geometry with an average bond distance of ca. $1.90 \AA$, which is consistent with those of analogous Co ${ }^{\mathrm{III}}$ complexes (Table 2) [4,10]. On the other hand, the geometry of the hexacoordinated Mn center was rather ambiguous. Such ambiguous geometry is a characteristic of $\mathrm{Mn}^{\mathrm{II}}$ complexes, which lack crystal field stabilization. The oxidation states of the metal centers were confirmed to be $\mathrm{Co}^{\mathrm{III}}$ and $\mathrm{Mn}^{\mathrm{II}}$ by bond valence sum analysis [11]. A positional disorder was observed at the methyl group of the coordinating methanol molecule with occupancy of ca. 0.5 (C28 and C28B). Furthermore, considerable disorder was observed for solvent molecules of crystallization. It is to be noted that the SQUEEZE program [12] was employed for structural refinement to treat the heavy disorder, and 10 electrons, which corresponds to a water molecule, in a $35 \AA^{3}$ void were removed. Such heavy disorder of the solvent molecules is illustrative of the fluid nature of the solvent-accessible void. 


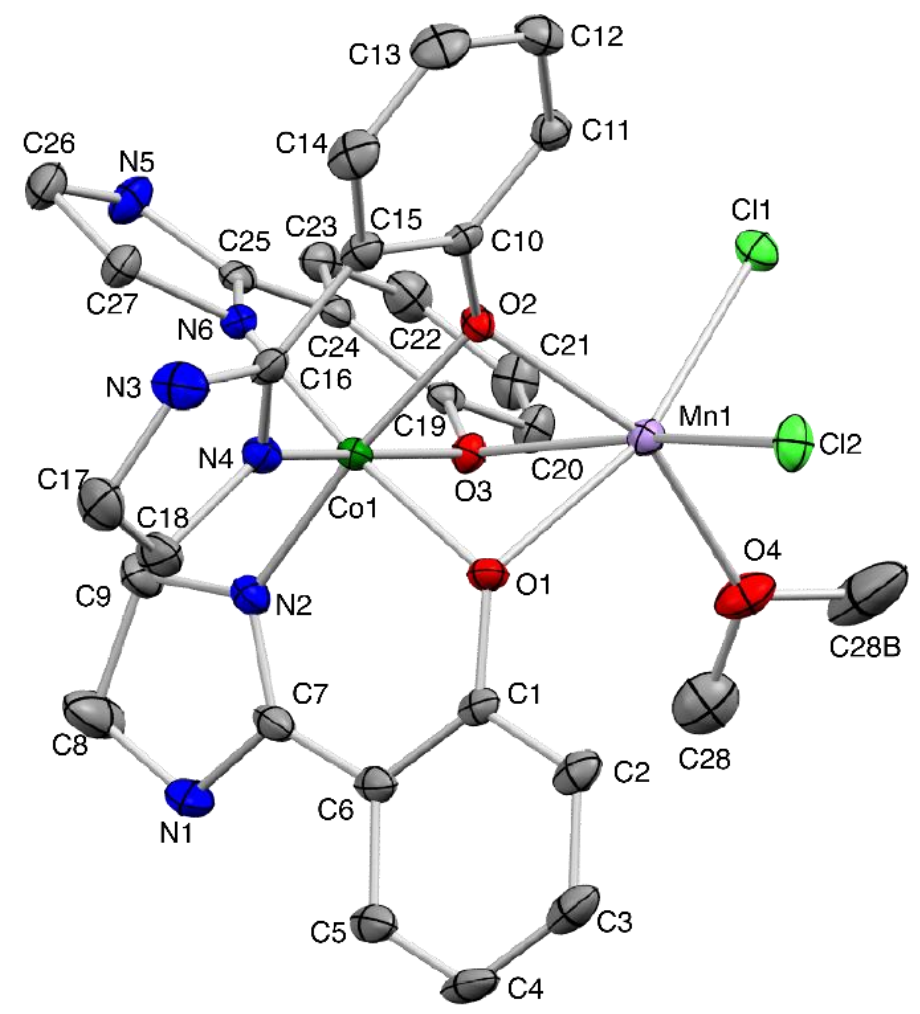

Figure 1. The molecular structure of $\left[\mathrm{Mn}\left\{\mathrm{Co}(\mu-\mathrm{Himn})_{3}\right\} \mathrm{Cl}_{2}\left(\mathrm{CH}_{3} \mathrm{OH}\right)\right](50 \%$ probability levels). Hydrogen atoms have been omitted for clarity. The disordered $\mathrm{C}$ atom of the coordinating methanol molecule is shown at the two possible positions (C28 and C28B).

Table 1. Crystallographic information.

\begin{tabular}{|c|c|}
\hline & {$\left[\mathrm{Co}(\mathrm{Himn})_{3} \mathrm{MnCl}_{2}\left(\mathrm{CH}_{3} \mathrm{OH}\right)\right] \cdot 0.78 \mathrm{CH}_{3} \mathrm{OH} \cdot 1.26 \mathrm{H}_{2} \mathrm{O}$} \\
\hline Chemical formula & $\mathrm{C}_{28.78} \mathrm{H}_{36.64} \mathrm{Cl}_{2} \mathrm{CoMnN}_{6} \mathrm{O}_{6.04}$ \\
\hline Formula weight & 748.05 \\
\hline Color and shape & brown, prism \\
\hline Size of specimen $/ \mathrm{mm}^{3}$ & $0.18 \times 0.12 \times 0.08$ \\
\hline Crystal system & monoclinic \\
\hline Space group & $P 2_{1} / n$ \\
\hline$a / \AA$ & $10.4888(13)$ \\
\hline$b / \AA$ & $14.4208(18)$ \\
\hline$c / \AA$ & $22.026(3)$ \\
\hline$\beta /^{\circ}$ & $102.460(2)$ \\
\hline$V / \AA^{3}$ & $3253.1(7)$ \\
\hline Z & 4 \\
\hline $\mathrm{T} / \mathrm{K}$ & $90(2)$ \\
\hline$D_{\text {calc }} / \mathrm{g} \mathrm{cm}^{-3}$ & 1.527 \\
\hline$F(000)$ & 1543 \\
\hline$\mu\left(M o-K_{\alpha}\right) / \mathrm{mm}^{-1}$ & 1.113 \\
\hline$R_{i n t}$ & 0.0361 \\
\hline $2 \theta_{\max } /^{\circ}$ & 55 \\
\hline No. of independent reflection & 7454 \\
\hline$R_{1}\left(F^{2}: F_{o}^{2}>2 \mathrm{~s}\left(F_{o}^{2}\right)\right)$ & 0.0533 \\
\hline$w R_{2}\left(F_{2}:\right.$ all data $)$ & 0.1282 \\
\hline
\end{tabular}


Table 2. Bond distances around the metal centers $(\AA)$.

\begin{tabular}{cccc}
\hline Bond & Distance & Bond & Distance \\
\hline Co1-O1 & $1.909(3)$ & Mn1-O1 & $3.229(3)$ \\
Co1-O2 & $1.898(2)$ & Mn1-O2 & $3.317(3)$ \\
Co1-O3 & $1.902(3)$ & Mn1-O3 & $2.263(2)$ \\
Co1-N2 & $1.906(3)$ & Mn1-O4 & $2.160(2)$ \\
Co1-N4 & $1.899(3)$ & Mn1-Cl1 & $2.464(1)$ \\
Co1-N6 & $1.903(3)$ & Mn1-Cl2 & $2.459(1)$ \\
\hline
\end{tabular}

\subsection{Supramolecular Structure}

A hydrogen-bonded supramolecular structure was constructed in $\left[\mathrm{Mn}^{\mathrm{II}}\left\{\mathrm{Co}^{\mathrm{III}}(\mu-\mathrm{Himn})_{3}\right\} \mathrm{Cl}_{2}\left(\mathrm{CH}_{3} \mathrm{OH}\right)\right] \cdot 0.78 \mathrm{CH}_{3} \mathrm{OH} \cdot 1.26 \mathrm{H}_{2} \mathrm{O}$ (Figure 2, Table 3). The ligand Himn ${ }^{-}$ potentially forms an intermolecular hydrogen-bond in the bidentate coordination mode $[4,10]$. It has been reported that $\left[\mathrm{Co}^{\mathrm{II}}\left\{\mathrm{Co}^{\mathrm{III}}(\mathrm{Himn})_{3}\right\}_{2}\right] \mathrm{Cl}_{2}$, which contains two $\mathrm{fac}-\left[\mathrm{Co}^{\mathrm{III}}(\mathrm{Himn})_{3}\right]$ as metalloligands, forms a crystallographically trigonal hydrogen-bonded sheet structure in the crystal because of the $C_{3}$ symmetry of $f a c-\left[\mathrm{Co}{ }^{\mathrm{III}}(\mathrm{Himn})_{3}\right]$. In $\left[\mathrm{Mn}^{\mathrm{II}}\left\{\mathrm{Co}{ }^{\mathrm{III}}(\mu-\mathrm{Himn})_{3}\right\} \mathrm{Cl}_{2}\left(\mathrm{CH}_{3} \mathrm{OH}\right)\right] \cdot 0.78 \mathrm{CH}_{3} \mathrm{OH} \cdot 1.26 \mathrm{H}_{2} \mathrm{O}$, on the other hand, the hydrogen-bond network was not trigonal, although all of the $\mathrm{N}-\mathrm{H}$ bonds form hydrogen bonds with the $\mathrm{Cl}^{-}$ligand of the neighboring complexes. This is presumably because of the nonsymmetric Mn center, which is coordinated by two $\mathrm{Cl}^{-}$ligands and a methanol molecule.

The nonsymmetric coordination geometry of the Mn center resulted in the formation of a supramolecular sheet structure in the $a b$ plane. As mentioned above, many solvent molecules of crystallization were observed in this crystal. These molecules are located between the hydrogen-bonded sheets-where a one-dimensional solvent-accessible void is formed-in which these disordered molecules are located. The shape of the void (534 $\AA^{3} /$ cell) in the packing diagram is shown in Figure 3.

(a)

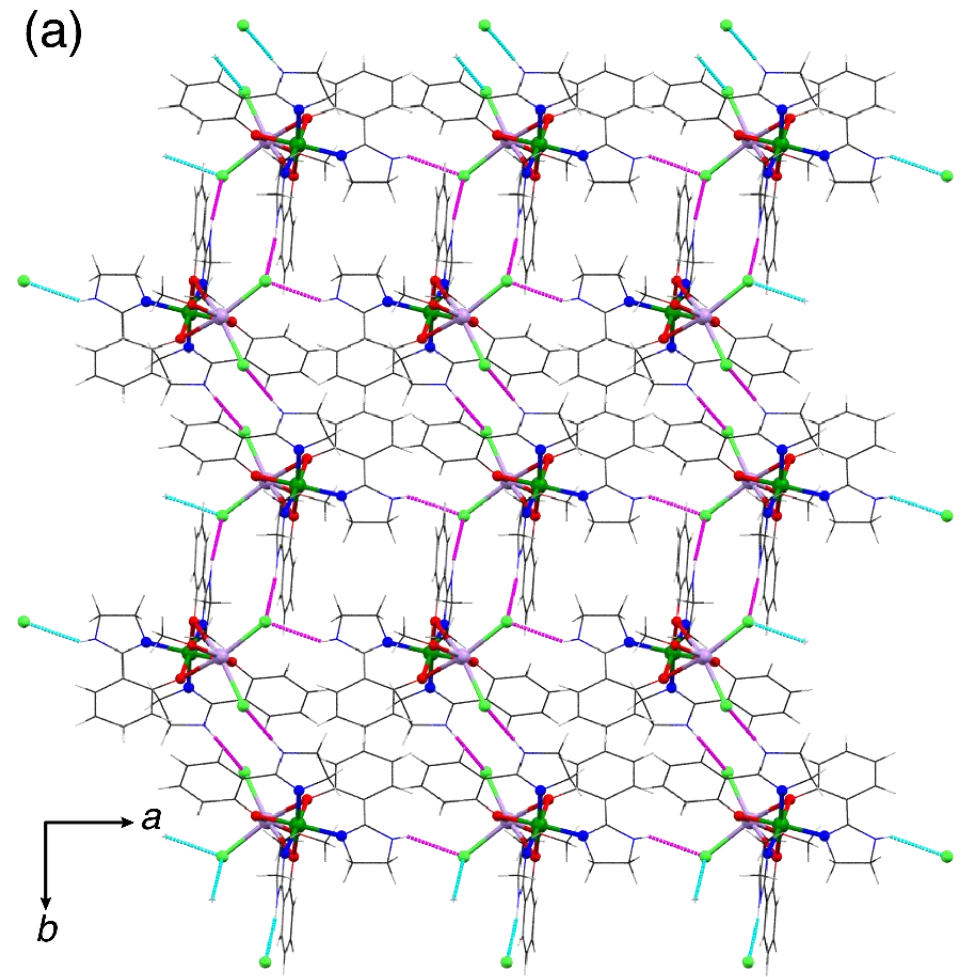

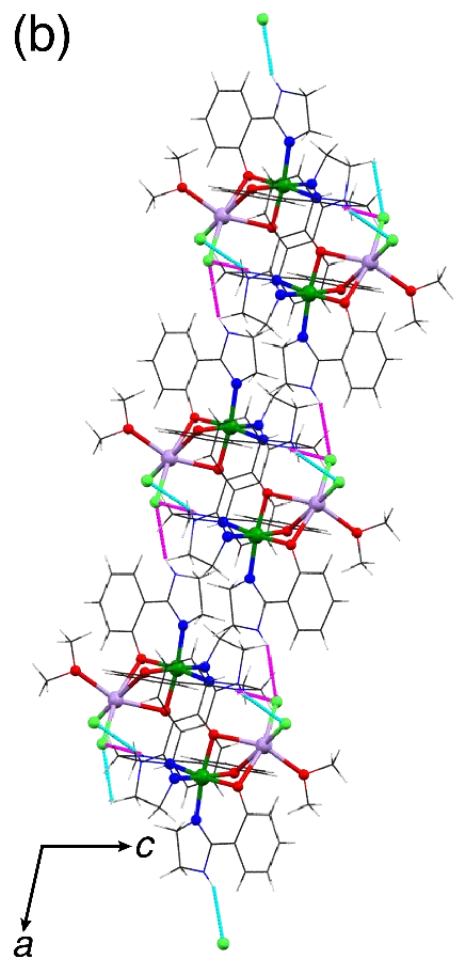

Figure 2. Hydrogen-bonded sheet structure of $\left[\mathrm{Mn}\left\{\mathrm{Co}(\mu-\mathrm{Himn})_{3}\right\} \mathrm{Cl}_{2}\left(\mathrm{CH}_{3} \mathrm{OH}\right)\right]$ in the $a b$ plane. Views along the (a) $c$ axis and (b) $b$ axis. 
(a)

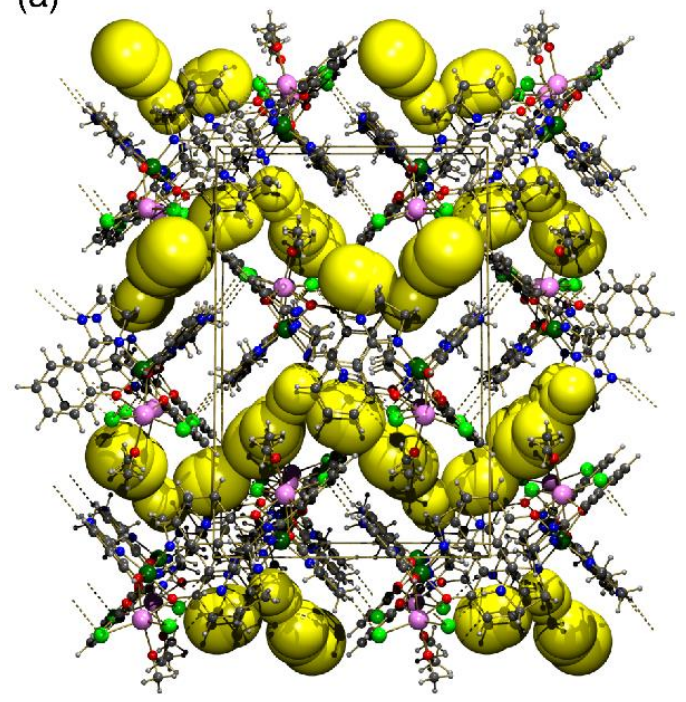

(b)

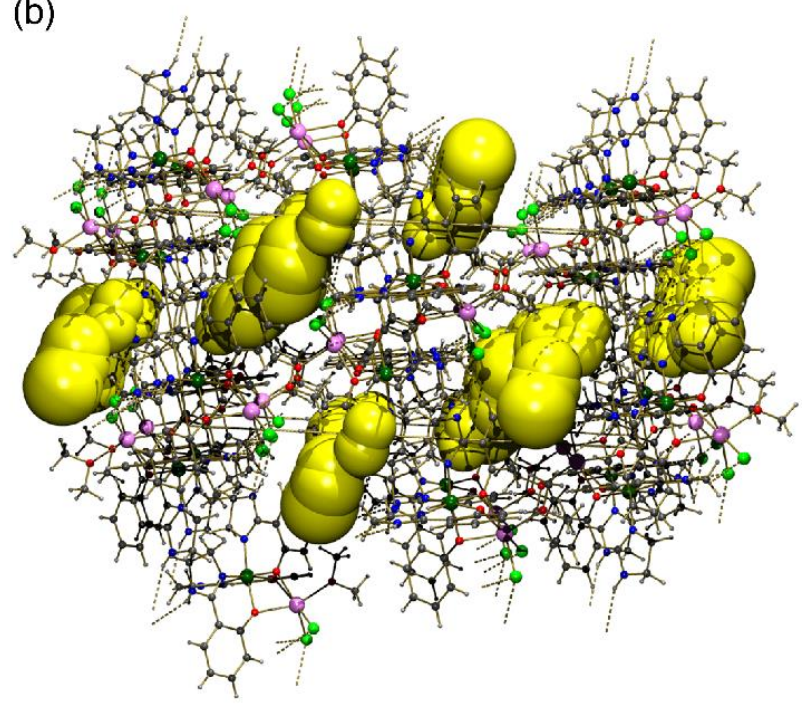

Figure 3. Packing diagram of $\left[\mathrm{Mn}\left\{\mathrm{Co}(\mu-\mathrm{Himn})_{3}\right\} \mathrm{Cl}_{2}\left(\mathrm{CH}_{3} \mathrm{OH}\right)\right]$ along (a) the $a$ axis and (b) the $b$ axis. The solvent-accessible void ( $534 \AA^{3}$ /cell) was observed between the hydrogen-bonded sheets (yellow sphere). Solvent molecules of crystallization were removed and regarded as solvent-accessible voids.

Table 3. Hydrogen-bond geometry for $\left[\mathrm{Mn}\left\{\mathrm{Co}(\mu-\mathrm{Himn})_{3}\right\} \mathrm{Cl}_{2}\left(\mathrm{CH}_{3} \mathrm{OH}\right)\right] \cdot 0.78 \mathrm{CH}_{3} \mathrm{OH} \cdot 1.26 \mathrm{H}_{2} \mathrm{O}\left(\AA{ }^{\circ}{ }^{\circ}\right)$.

\begin{tabular}{|c|c|c|c|c|}
\hline$D-H \cdots A$ & $D-H$ & $H \cdots A$ & $D \cdots A$ & $D-A \cdots A$ \\
\hline $\mathrm{N} 1-\mathrm{H} 1 \cdots \mathrm{Cl} 1^{\mathrm{i}}$ & $0.75(4)$ & $2.59(5)$ & $3.229(3)$ & $145(5)$ \\
\hline N3-H3A $\cdots \mathrm{Cl} 2^{\mathrm{ii}}$ & $0.75(4)$ & $2.63(4)$ & $3.317(3)$ & $153(4)$ \\
\hline N5-H5A …Cl1 (iii) & 0.88 & 2.50 & $3.268(3)$ & 146 \\
\hline O5-H5M… & 0.84 & 2.44 & $3.272(7)$ & 169 \\
\hline
\end{tabular}

\subsection{Magnetic Properties}

To investigate the magnetic properties, the temperature dependence of the $\chi_{M} T$ product and field dependence of the magnetization for $\left[\mathrm{Mn}^{\mathrm{II}}\left\{\mathrm{Co} \mathrm{CoI}^{\mathrm{III}}(\mu-\mathrm{Himn})_{3}\right\} \mathrm{Cl}_{2}\left(\mathrm{CH}_{3} \mathrm{OH}\right)\right] \cdot 0.78 \mathrm{CH}_{3} \mathrm{OH} \cdot 1.26 \mathrm{H}_{2} \mathrm{O}$ were measured (Figure 4). The $\chi_{M} T$ value at $300 \mathrm{~K}$ was $4.39 \mathrm{~cm}^{3} \mathrm{~K} \mathrm{~mol}^{-1}$, which is consistent with the spin-only value of $4.375 \mathrm{~cm}^{3} \mathrm{~K} \mathrm{~mol}^{-1}$ for the $S=5 / 2$ system. Upon cooling down to $5 \mathrm{~K}$, almost no change in the $\chi_{M} T$ value was observed, which is typical Curie-Weiss behavior. In the magnetization vs. field plot, the magnetization is nearly saturated in the presence of a dc field of $5 \mathrm{~T}$. These magnetic properties are characteristic of the isotropic $\mathrm{Mn}^{\mathrm{II}}$ center without magnetic coupling. To determine the $g$-factor, the temperature dependence of the magnetization and field dependence of the magnetization were simultaneously fitted with the following spin Hamiltonian using the PHI program [13].

$$
H=g \beta S H .
$$

Both of the data were well-fitted by the PHI program without considering zero-field splitting and intermolecular interactions. The $g$-factor was determined to be 2.00 . 
(a)

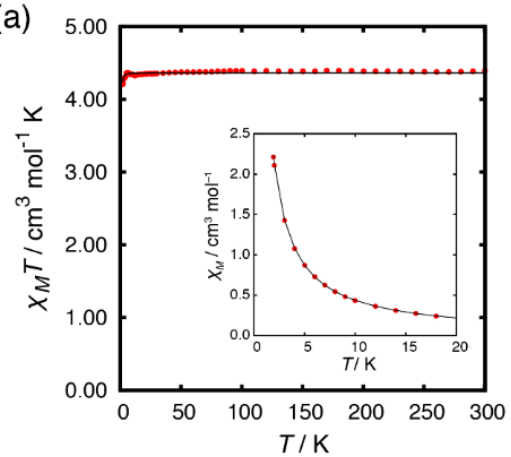

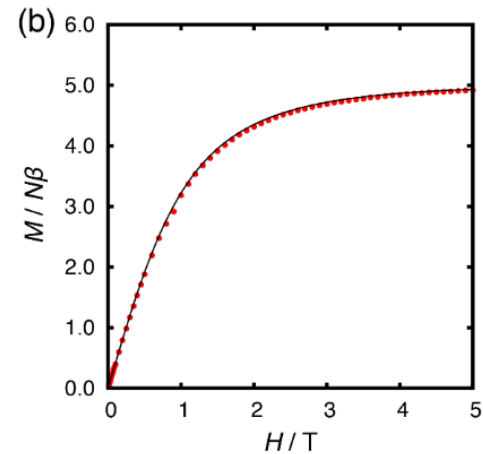

Figure 4. (a) Temperature dependence of the $\chi_{M} T$ product of $\left[\mathrm{Mn}^{\mathrm{II}}\left\{\mathrm{Co}{ }^{\mathrm{III}}(\mu-\mathrm{Himn})_{3}\right\} \mathrm{Cl}_{2}\left(\mathrm{CH}_{3} \mathrm{OH}\right)\right]$ in the presence of a $0.3 \mathrm{~T}$ static field and an $\chi_{M}$ vs. $T$ plot below $20 \mathrm{~K}$ (inset). (b) Field dependence of the magnetization of $\left[\mathrm{Mn}^{\mathrm{II}}\left\{\mathrm{Co}{ }^{\mathrm{III}}(\mu-\mathrm{Himn})_{3}\right\} \mathrm{Cl}_{2}\left(\mathrm{CH}_{3} \mathrm{OH}\right)\right]$ at $1.9 \mathrm{~K}$. The solid lines correspond to the fit using the $\mathrm{PHI}$ program. The magnetization fit is the same as fitting with a Brillouin function.

\section{Materials and Methods}

\subsection{General Consideration}

All chemicals were used as received without further purification.

\subsection{Synthetic Method}

The ligand, 2-(2-imidazolinyl)phenol $\left(\mathrm{H}_{2} \mathrm{imn}\right)$, was prepared according to a previously reported method [14]. To a methanol solution $(10 \mathrm{~mL})$ of $\mathrm{CoCl}_{2} \cdot 6 \mathrm{H}_{2} \mathrm{O}(24.2 \mathrm{mg}, 0.1 \mathrm{mmol})$ and $\mathrm{H}_{2} \mathrm{imn}(47.1 \mathrm{mg}$, $0.3 \mathrm{mmol})$ was slowly added a methanol solution of $\mathrm{KO}^{t} \mathrm{Bu}(32.8 \mathrm{mg}, 0.3 \mathrm{mmol})$. The reaction mixture was stirred overnight at room temperature in air and then evaporated to dryness. The resultant green residue was dissolved in methanol $(5 \mathrm{~mL})$, and the insoluble white residue was removed by filtration. The filtrate was degassed by bubbling $\mathrm{N}_{2}$ gas, and then a $5 \mathrm{~mL}$ methanol solution of $\mathrm{MnCl}_{2} \cdot 6 \mathrm{H}_{2} \mathrm{O}$ $(18.0 \mathrm{mg}, 0.1 \mathrm{mmol})$ was added. The reaction mixture was allowed to stand at room temperature under a $\mathrm{N}_{2}$ atmosphere for two weeks, and brown crystals were obtained. Yield: $14.1 \mathrm{mg}, 37 \%$. Anal. Calcd for $\left[\mathrm{Co}(\mathrm{Himn})_{3} \mathrm{MnCl}_{2}\left(\mathrm{CH}_{3} \mathrm{OH}\right)\right] \cdot \mathrm{CH}_{3} \mathrm{OH} \cdot 2.5 \mathrm{H}_{2} \mathrm{O}=\mathrm{C}_{29} \mathrm{H}_{40} \mathrm{Cl}_{2} \mathrm{CoN}_{6} \mathrm{O}_{7.5}: \mathrm{C}, 44.80 ; \mathrm{H}, 5.19 ; \mathrm{N}, 10.81 \%$. Found: C, 44.46; H, 4.85; N, 11.05\%.

\subsection{Single-Crystal X-ray Crystallography}

X-ray diffraction data were obtained at 90(2) K using a Bruker SMART APEX diffractometer system with graphite-monochromated Mo K $\alpha$ radiation $(\lambda=0.71073 \AA)$. A single crystal was mounted with a glass capillary and flash-cooled with a cold nitrogen gas stream. Data were processed using Bruker APEX III software packages. Absorption correction was applied using empirical methods [15]. Structures were solved using SHELXT software packages and refined on $F^{2}$ (with all independent reflections) using a SHELXL software package $[16,17] .13$ In the structural refinement, all C-H atoms were located using a riding model and refined isotropically. The positions of the $\mathrm{N}-\mathrm{H}$ and $\mathrm{O}-\mathrm{H}$ atoms were determined from difference-Fourier maps and freely refined except for the N5-H5A atom. The N5-H5 atom was located using a riding model because it could not be located from the difference-Fourier maps. Some low-angle reflections were omitted from the refinement because these reflections were likely to be affected by the beam stopper. Reflections due to solvent disorder located in the void spaces between the two-dimensional sheet structure were treated using the SQUEEZE program [17]. Here, 10 electrons in the $35 \AA^{3} /$ void were removed. The crystallographic data were deposited with the Cambridge Crystallographic Data Centre: Deposition number CCDC-1887480. These data can be obtained free of charge via www.ccdc.cam.ac.uk/data_request/cif (or from the Cambridge Crystallographic Data Centre, 12, Union Road, Cambridge, CB2 1EZ, UK; Fax, +44-1223-336033; e-mail: deposit@ccdc.cam.ac.uk). 


\subsection{Magnetic Measurements}

Magnetic susceptibility measurements were performed using an MPMS-7 SQUID magnetometer. Susceptibility data were obtained in the temperature range from 1.9 to $300 \mathrm{~K}$ with a static field of $0.3 \mathrm{~T}$. The field dependence of the magnetization was measured at $1.9 \mathrm{~K}$ in the field range from 0 to $5 \mathrm{~T}$. The polycrystalline sample was ground into fine powders by an agate mortar. The samples were loaded into a gelatin capsule. The sampling was handled in air. All data were corrected for diamagnetism of the sample by means of Pascal's constants.

\section{Conclusions}

We succeeded in preparing a heterodinuclear $\mathrm{Co}^{\mathrm{III}}-\mathrm{Mn}^{\mathrm{II}}$ complex by a metalloligand synthesis approach. Non-coordinating $\mathrm{N}-\mathrm{H}$ bonds in the metalloligand induced the formation of intermolecular hydrogen bonds to construct a two-dimensional sheet structure. The magnetic susceptibility measurements indicated that intermolecular interactions and zero-field splitting are negligible in this complex. The negligible intermolecular interactions imply that analogous complexes with an anisotropic paramagnetic ion instead of $\mathrm{Mn}^{\mathrm{II}}$ may be a candidate for magnetically well-isolated single-molecule magnets.

Author Contributions: R.M. designed and performed the experiment, analyzed the data, and wrote the manuscript. T.U. performed a part of the experiments. M.M. took part in the discussion.

Funding: This research received no external funding.

Acknowledgments: We are indebted to Takayoshi Suzuki (Okayama Univ.) for valuable discussions. All the magnetic measurements were conducted at the Institute of Molecular Science, supported by the Nanotechnology Platform (Molecule and Material Synthesis) of MEXT, Japan.

Conflicts of Interest: The authors declare no conflict of interest.

\section{References}

1. Sessoli, R.; Gatteschi, D.; Caneschi, A.; Novak, M.A. Magnetic bistability in a metal-ion cluster. Nature 1993, 365, 141-143. [CrossRef]

2. Zadrozny, J.M.; Long, J.R. Slow magnetic relaxation at zero field in the tetrahedral complex $\left[\mathrm{Co}(\mathrm{SPh})_{4}\right]^{2-}$. J. Am. Chem. Soc. 2011, 133, 20732-20734. [CrossRef] [PubMed]

3. Novikov, V.V.; Pavlov, A.A.; Nelyubina, Y.V.; Boulon, M.-E.; Varzatskii, O.A.; Voloshin, Y.Z.; Winpenny, R.E.P. A Trigonal Prismatic Mononuclear Cobalt(II) Complex Showing Single-Molecule Magnet Behavior. J. Am. Chem. Soc. 2015, 137, 9792-9795. [CrossRef] [PubMed]

4. Mitsuhashi, R.; Pedersen, K.S.; Ueda, T.; Suzuki, T.; Bendix, J.; Mikuriya, M. Field-induced single-molecule magnet behavior in ideal trigonal antiprismatic cobalt(II) complexes: precise geometrical control by a hydrogen-bonded rigid metalloligand. Chem. Commun. 2018, 54, 8869-8872. [CrossRef] [PubMed]

5. Mitsuhashi, R.; Hosoya, S.; Suzuki, T.; Sunatsuki, Y.; Sakiyama, H.; Mikuriya, M. Hydrogen-bonding interactions and magnetic relaxation dynamics in tetracoordinated cobalt(II) single-ion magnets. Dalton Trans. 2019, 48, 395-399. [CrossRef] [PubMed]

6. Rosado Piquer, L.; Sañudo, E.C. Heterometallic 3d-4f single-molecule magnets. Dalton Trans. 2015, 44, 8771-8780. [CrossRef] [PubMed]

7. Colacio, E.; Ruiz, J.; Ruiz, E.; Cremades, E.; Krzystek, J.; Carretta, S.; Cano, J.; Guidi, T.; Wernsdorfer, W.; Brechin, E.K. Slow Magnetic Relaxation in a $\mathrm{Co}^{\mathrm{II}}-\mathrm{Y}^{\mathrm{III}}$ Single-Ion Magnet with Positive Axial Zero-Field Splitting. Angew. Chemie Int. Ed. 2013, 52, 9130-9134. [CrossRef] [PubMed]

8. Sørensen, M.A.; Weihe, H.; Vinum, M.G.; Mortensen, J.S.; Doerrer, L.H.; Bendix, J. Imposing high-symmetry and tuneable geometry on lanthanide centres with chelating Pt and Pd metalloligands. Chem. Sci. 2017, 8, 3566-3575. [CrossRef] [PubMed]

9. Sørensen, M.A.; Hansen, U.B.; Perfetti, M.; Pedersen, K.S.; Bartolomé, E.; Simeoni, G.G.; Mutka, H.; Rols, S.; Jeong, M.; Zivkovic, I.; et al. Chemical tunnel-splitting-engineering in a dysprosium-based molecular nanomagnet. Nat. Commun. 2018, 9, 1292. [CrossRef] 
10. Mitsuhashi, R.; Suzuki, T.; Hosoya, S.; Mikuriya, M. Hydrogen-Bonded Supramolecular Structures of Cobalt(III) Complexes with Unsymmetrical Bidentate Ligands: mer/fac Interconversion Induced by Hydrogen-Bonding Interactions. Cryst. Growth Des. 2017, 17, 207-213. [CrossRef]

11. Liu, W.; Thorp, H.H. Bond Valence Sum Analysis of Metal-Ligand Bond Lengths in Metalloenzymes and Model Complexes. 2. Refined Distances and Other Enzymes. Inorg. Chem. 1993, 32, 4102-4105. [CrossRef]

12. Spek, A.L. PLATON SQUEEZE: A tool for the calculation of the disordered solvent contribution to the calculated structure factors. Acta Crystallogr. Sect. C Struct. Chem. 2015, 71, 9-18. [CrossRef] [PubMed]

13. Chilton, N.F.; Anderson, R.P.; Turner, L.D.; Soncini, A.; Murray, K.S. PHI: A powerful new program for the analysis of anisotropic monomeric and exchange-coupled polynuclear d- and f-block complexes. J. Comput. Chem. 2013, 34, 1164-1175. [CrossRef] [PubMed]

14. Mitsuhashi, R.; Suzuki, T.; Sunatsuki, Y. Four-Electron Oxidative Dehydrogenation Induced by Proton-Coupled Electron Transfer in Ruthenium(III) Complex with 2-(1,4,5,6-Tetrahydropyrimidin2-yl)phenolate. Inorg. Chem. 2013, 52, 10183-10190. [CrossRef] [PubMed]

15. Bruker. SADABS, Program for Absorption Correction; Bruker AXS Inc.: Madison, WI, USA, 2001.

16. Sheldrick, G.M. A short history of SHELX. Acta Crystallogr. Sect. A: Found. Adv. 2015, 71, 3-8. [CrossRef] [PubMed]

17. Sheldrick, G.M. Crystal structure refinement with SHELXL. Acta Crystallogr. Sect. C: Struct. Chem. 2015, 71, 3-8. [CrossRef] [PubMed]

(C) 2019 by the authors. Licensee MDPI, Basel, Switzerland. This article is an open access article distributed under the terms and conditions of the Creative Commons Attribution (CC BY) license (http://creativecommons.org/licenses/by/4.0/). 